\title{
Comparison of jejunal digestive enzyme activities, expression of nutrient transporter genes, and apparent fecal digestibility in weaned piglets fed diets with varied sources of fiber
}

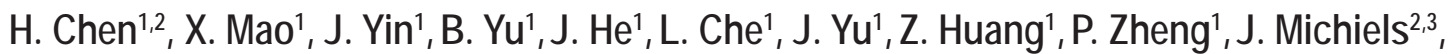 \\ S. De Smet ${ }^{2}$ and D. Chen ${ }^{1,4}$ \\ ${ }^{1}$ Sichuan Agricultural University, College of Food Science, Institute of Animal Nutrition \\ No.46. Xinkang Road, Yucheng district, Yaan, Sichuan 625014, China \\ ${ }^{2}$ Ghent University, Department of Animal Production, Laboratory for Animal Nutrition and Animal Product Quality (LANUPRO) \\ Proefhoevestraat 10, 9090 Melle, Belgium \\ ${ }^{3}$ University College Ghent, Faculty of Applied Bioscience Engineering, Valentin Vaerwyckweg 1, 9000 Gent, Belgium
}

KEY WORDS: dietary fiber, piglet, digestive enzymes, nutrient transporters, digestibility

Received: 5 August 2014

Revised: 25 February 2015

Accepted: 16 March 2015

\begin{abstract}
The objective of this study was to evaluate the effect of different fiber sources on jejunal digestive and absorptive physiology in weaned piglets. One hundred weaned piglets were allotted according to body weight, gender and litter to four dietary treatments. Each treatment was replicated in 5 pens of 5 pigs each. The experimental diets contained $10 \%$ of a fiber source: wheat bran (WB), maize fiber (MF), soyabean fiber (SF), or pea fiber (PF). Piglets were fed ad libitum for $30 \mathrm{~d}$. Reduced villus height and villus height-to-crypt depth ratio $(P<0.05)$ were observed in pigs fed diet MF compared with pigs fed diet WB. In the mid-jejunal mucosa, lower activities of sucrase $(P<0.05)$ were found in pigs fed diets MF and SF compared with WB. In mid-jejunal digesta, inclusion of SF and PF decreased the activities of trypsin and lipase $(P<0.05)$ compared with inclusion of WB. Supplementation with PF resulted in higher facilitated glucose transporter $2(P<0.05)$ and lower excitatory amino acid carrier $1 \mathrm{mRNA}$ levels compared with supplementing WB. The apparent faecal digestibility of gross energy, dry matter, organic matter, neutral detergent fiber and acid detergent fiber declined in the following order: diet SF > PF > MF > WB. Our study indicates that SF and PF could promote apparent faecal digestibility in piglets, but this is not accompanied by better jejunal morphology or digestive enzyme activities as compared with WB.
\end{abstract}

${ }^{4}$ Corresponding author: e-mail: dwchen@sicau.edu.cn
To make a rational choice of dietary fiber for piglet diets, it is necessary to determine the effect of different fiber sources on digestive physiology.

Several studies on feeding supplemental fiber to pigs have shown that the source of dietary fiber plays a significant role in digestion and absorption. Growing pigs fed soyabean hulls showed a higher digestibility of energy than those fed pea hulls and 
millet hulls (Wenk and Zurcher, 1990). The apparent digestibility of energy, crude protein, and dry matter of pigs fed a carboxymethylcellulose-rich diet was higher than when fed a cellulose- or $\beta$-glucanenriched diet (Hooda et al., 2010). It has been shown that longer villi in the jejunum correspond to higher activity of saccharidases, which play a fundamental role in digestion (Pluske et al., 1996). Moreover, it is known that the glucose transporters: $\mathrm{Na}+$-glucose co-transporter 1 (SGLT1) and facilitated glucose transporter 2 (GLUT2); amino acid transporters: $\mathrm{Na}+$-dependent neutral amino acid transporter (B0), cationic amino acid transporter 1 (CAT1) and excitatory amino acid carrier 1 (EAAC1), and peptide transporter T1 (PepT1) in the small intestinal epithelium are closely associated with nutrient absorption capacity (Regnault et al., 2002; Hu et al., 2008; Roder et al., 2014). However, it is not clear how dietary fiber influences nutrient digestibility by regulating jejunal morphological characteristics and nutrient transporters.

Wheat bran, a frequently-used fiber source, has been reported to affect digestive enzyme activities and nutrient apparent digestibility in pigs (Ma et al., 2002; Wilfart et al., 2007b). Effects of the potential fiber sources on the digestive physiology of piglets (i.e., of maize fiber, soyabean fiber, and pea fiber) in our previous study (Chen et al., 2013) were inconclusive. Therefore, the present study was designed to study the effect of fiber sources on mid-jejunal digestive enzyme activities, morphology, expression of nutrient transporter genes and apparent fecal digestibility in weaned piglets compared with a frequently-used fiber source (wheat bran).

\section{Material and methods}

The experimental protocols were approved by the Sichuan Agricultural University Institutional Animal Care and Use Committee (Ya'an, China).

\section{Preparation of dietary fiber}

Wheat bran, maize fiber, soyabean fiber and pea fiber were purchased from Chinese food companies. The fibers were purified from wheat, maize, soyabean and pea, respectively, by extracting starch and protein following common industrial processing.

\section{Experimental design, diets, and sampling}

A total of 100 crossbred piglets (Duroc $\times$ Landrace $\times$ Yorkshire), weaned at 28 days of age were assigned to 4 treatments depending on body weight, gender and litter. The same gender ratio of piglets was maintained in each treatment. Each dietary treatment was replicated in 5 pens of 5 pigs each, and piglets were fed ad libitum for $30 \mathrm{~d}$. The environmental temperature was maintained at $26^{\circ} \mathrm{C}$ for the first $3 \mathrm{~d}$ after weaning and then reduced by $2^{\circ} \mathrm{C}$ per week for the remainder of the experiment. Expanded maize, dehulled soyabean meal, maize starch and soya protein concentrate were used as the main feed ingredients in the experimental diets in order to reduce the interference of fiber content in non-fiber source ingredients (Table 1). Experimental diets

Table 1. Composition of experimental diets (as-fed basis)

\begin{tabular}{lcccc}
\hline \multirow{2}{*}{ Item } & \multicolumn{5}{l}{ Experimental diets } \\
\cline { 2 - 5 } & WB & MF & SF & PF \\
\hline Ingredient, \% & & & & \\
expanded maize & 24.68 & 24.68 & 24.68 & 24.68 \\
dehulled soyabean meal, & 19.00 & 19.00 & 19.00 & 19.00 \\
47.9\% & 20.00 & 20.00 & 20.00 & 20.00 \\
maize starch & 5.00 & 5.00 & 5.00 & 5.00 \\
fishmeal, 62.5\% & 5.00 & 5.00 & 5.00 & 5.00 \\
soya protein concentrate, $65 \%$ & 4.00 & 4.00 & 4.00 & 4.00 \\
whey powder & 3.00 & 3.00 & 3.00 & 3.00 \\
sucrose & 3.00 & 3.00 & 3.00 & 3.00 \\
glucose & 3.00 & 3.00 & 3.00 & 3.00 \\
fat powder ${ }^{1}$ & 10.00 & & - & - \\
wheat bran & - & 10.00 & - & - \\
maize fiber & & - & 10.00 & - \\
soyabean fiber & - & - & - & 10.00 \\
pea fiber & 0.20 & 0.20 & 0.20 & 0.20 \\
salt & 0.45 & 0.45 & 0.45 & 0.45 \\
L-lysine HCl, $75 \%$ & 0.29 & 0.29 & 0.29 & 0.29 \\
DL-metheonine & 0.20 & 0.20 & 0.20 & 0.20 \\
L-threonine & 0.05 & 0.05 & 0.05 & 0.05 \\
L-tryptphane & 0.90 & 0.90 & 0.90 & 0.90 \\
limestone & 0.89 & 0.89 & 0.89 & 0.89 \\
monocalcium phosphate & 0.10 & 0.10 & 0.10 & 0.10 \\
choline chloride, $50 \%$ & 0.04 & 0.04 & 0.04 & 0.04 \\
vitamin premix ${ }^{2}$ & 0.20 & 0.20 & 0.20 & 0.20 \\
trace mineral premix & & 100.00 & 100.00 & 100.00 \\
total & & & &
\end{tabular}

\section{Chemical composition}

\begin{tabular}{lrrrr} 
dry matter, \% ${ }^{4}$ & 90.63 & 89.91 & 89.93 & 90.40 \\
gross energy, MJ $\cdot \mathrm{kg}^{-1,4}$ & 16.17 & 16.17 & 15.95 & 16.62 \\
crude protein, \% ${ }^{4}$ & 19.09 & 18.59 & 18.93 & 18.73 \\
lysine, ${ }^{5}$ & 1.40 & 1.40 & 1.40 & 1.40 \\
$\mathrm{Ca}, \%^{4}$ & 0.83 & 0.54 & 0.45 & 0.84 \\
$\mathrm{P}$ available, \% ${ }^{5}$ & 0.45 & 0.45 & 0.45 & 0.45 \\
$\mathrm{P}$ total, \% ${ }^{4}$ & 0.64 & 0.55 & 0.55 & 0.53 \\
crude fiber, \% ${ }^{4}$ & 3.82 & 3.87 & 3.53 & 4.95 \\
neutral detergent fiber, $\%{ }^{4}$ & 13.41 & 12.69 & 10.77 & 11.02 \\
acid detergent fiber, \% ${ }^{4}$ & 4.12 & 3.68 & 3.48 & 5.26 \\
\hline
\end{tabular}

WB - wheat bran diet, MF - maize fiber diet, SF - soyabean fiber diet, PF - pea fiber diet; ${ }^{1}$ made of palm oils, produced by Shandong Tianjiao Biotech Co., Ltd.; ${ }^{2}$ providing per kg of diet: $\mathrm{mg}$ : vit. A 4.05, vit. E 24, vit. $K_{3} 3$, vit. $B_{1} 3$, vit. $B_{2} 6$, vit. $B_{6} 3$, pantothenic acid 15 , folic acid 1.2: $\mu$ g: biotin 150 , vit. $\mathrm{D}_{3} 52.25$, vit. $\mathrm{B}_{12} 24 ;{ }^{3}$ providing per kg of diet: $\mathrm{mg}$ : Fe (as $\mathrm{FeSO}_{4} \cdot 7 \mathrm{H}_{2} \mathrm{O}$ ) 110, $\mathrm{Cu}$ (as CuSO$\cdot 5 \mathrm{H}_{2} \mathrm{O}$ ) 10, $\mathrm{Zn}$ (as ZnSO$\cdot 7 \mathrm{H}_{2} \mathrm{O}$ ) 110, $\mathrm{Mn}\left(\right.$ as $\left.\mathrm{MnSO}_{4} \cdot \mathrm{H}_{2} \mathrm{O}\right) 6$, I (as KI) 0.3, Se (as $\left.\mathrm{Na}_{2} \mathrm{SeO}_{3}\right) 0.3 ;{ }^{4}$ analysed value; ${ }^{5}$ calculated value 
included $10 \%$ of the following fiber sources: wheat bran (WB), maize fiber (MF), soyabean fiber (SF) and pea fiber $(\mathrm{PF})$. The pigs were weighed on day 0 and at the end of the experiment, i.e., after $30 \mathrm{~d}$. Voluntary feed intake was recorded and daily weight gain and feed conversion ratio were calculated. From $21 \mathrm{~d}$, chromic oxide $\left(4 \mathrm{~g} \cdot \mathrm{kg}^{-1}\right)$ was added to the experimental diets. Fresh fecal samples were collected from every pen on days 25, 26, 27 and 28, weighed and stored at $-20^{\circ} \mathrm{C}$, then lyophilized prior to analysis for determination of apparent fecal digestibility.

On day 30, one piglet from each pen was randomly selected and anaesthetized by a lethal injection of sodium pentobarbital (200 mg $\cdot \mathrm{kg}^{-1} \mathrm{BW}$ ). The abdomen was immediately opened to remove the jejunum. The digesta in the mid-jejunum were collected, immediately snap-frozen in liquid nitrogen and stored at $-20^{\circ} \mathrm{C}$ for analysis of digestive enzyme activity. Intestinal segments $(2 \mathrm{~cm})$ from the mid-jejunum were collected and fixed in 10\% formaldehyde buffer for intestinal morphology analysis. Samples of mucosa (3 g) scraped from the mid-jejunum were immediately snap-frozen in liquid nitrogen, then stored at $-80^{\circ} \mathrm{C}$ until analysis for disaccharidase activity and for gene expression of transporter proteins using RT-PCR.

\section{Determination of mid-jejunal morphology}

Consecutive $3 \mu \mathrm{m}$ thick-sections of the intestinal samples were stained with hematoxylin-eosin for histomorphologic examination after fixation and embedding in paraffin. Villus height and crypt depth were determined at $40 \times$ magnification using an Olympus CK 40 microscope (Olympus Optical Company, Shenzhen, China). A minimum of 10 villi (V) and crypts (C) were measured per piglet.

\section{Mid-jejunal digestive enzyme analysis}

The gut tissue samples were rinsed before scraping off the mucosa. The mucosal scrapings and digesta were homogenized in physiological saline at a 1:5 ratio $\left(\mathrm{g} \cdot \mathrm{ml}^{-1}\right)$. The homogenate was centrifuged at $1250 \mathrm{~g}$ and $4^{\circ} \mathrm{C}$ for $10 \mathrm{~min}$. The supernatant was analysed for protein content and enzyme activities. The total protein content of the intestinal samples was measured by the Bradford method. In jejunal digesta, the activities of trypsin, lipase and amylase were measured using commercial kits (Jiancheng Bioengineering Institute, Nanjing, China). In jejunal mucosa, the activities of lactase, sucrase and maltase were assayed using commercial kits (Jiancheng Bioengineering Institute, Nanjing, China) to determine the amount of liberated glucose. Enzyme activities are presented as units (U) per milligram or gram of protein.

\section{Detection of mRNA expression by Real-Time RT-PCR}

Frozen samples of jejunal mucosa (0.1 g) were homogenized in $1 \mathrm{ml}$ TRIzol reagent (Invitrogen, Dalian, China), and then total RNA was extracted according to the manufacturer's instructions. Precipitated nucleic acids were dried and resuspended in $50 \mu \mathrm{l}$ of sterile purified water after being washed with $75 \%$ ethanol. RNA was treated with DNase-I (TaKaRa, Tokyo, Japan) to remove traces of DNA. The concentration and purity of the RNA were assayed spectrophotometrically (Beckman Coulter DU800, Maryland, USA). The OD260:OD280 ratio ranged from 1.8 to 2.0 for all samples. The integrity of the RNA was determined by agarose gel electrophoresis and the 28S:18S ribosomal RNA bands ratio was found to be $\geq 2.0$.

The RNA samples were reverse transcribed into cDNA using PrimeScriptTM RT reagent kits (Takara, Tokyo, Japan) following the manufacturer's instructions. Primers (Table 2) were designed by Primer 6 following mRNA sequences of the pig intestinal tract downloaded from the GenBank database and synthesized commercially by Life Technologies Ltd. (Beijing, China). Real-Time PCR for quantification of SGLT1 (M34044.1), GLUT2

Table 2. Sequences of primers for the intestinal nutrients transporters genes

\begin{tabular}{|c|c|c|c|}
\hline Primer & Nucleotide Sequence (5'-3') & $\begin{array}{l}\text { Annealing } \\
\text { temp }\left({ }^{\circ} \mathrm{C}\right)\end{array}$ & $\begin{array}{l}\text { Product } \\
\text { size (bp) }\end{array}$ \\
\hline \multicolumn{4}{|l|}{$\beta$-actin } \\
\hline forward & TCTGGCACCACACCTTCT & 57.0 & 114 \\
\hline reverse & tGATCTGGGTCATCTTCTCAC & & \\
\hline \multicolumn{4}{|l|}{ SGLT1 } \\
\hline forward & TGTATTTGAGGCCAGTGTCA & 62.5 & 198 \\
\hline reverse & gGGCGACCACAACTCTTAAA & & \\
\hline \multicolumn{4}{|l|}{ GLUT2 } \\
\hline forward & TGGAATCAGCCAACCTGTTT & 53.5 & 165 \\
\hline reverse & aCAAGTCCCACCGACATGA & & \\
\hline \multicolumn{4}{|c|}{ 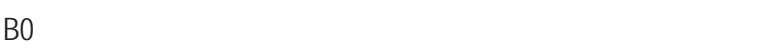 } \\
\hline forward & ACAACAACTGCGAGAAGGACTC & 59.5 & 164 \\
\hline reverse & GCAGGTCAAACCCGTTGATAAG & & \\
\hline \multicolumn{4}{|l|}{ CAT1 } \\
\hline forward & CCATGCCGCGAGTTATCTAT & 59.5 & 104 \\
\hline reverse & GGCTAACGTGGCGATTATTG & & \\
\hline \multicolumn{4}{|l|}{ EAAC1 } \\
\hline forward & CAAACTGGGCCTTTACATGG & 59.5 & 169 \\
\hline reverse & GTGTTGCTGAACTGGAGGAGAT & & \\
\hline \multicolumn{4}{|l|}{ PepT1 } \\
\hline forward & TGCTTCGGTTATCCCTTGAG & 59.5 & 185 \\
\hline reverse & CCTAGAATGGGCGTCAGGTA & & \\
\hline
\end{tabular}

SGLT1 - Na+-glucose co-transporter 1, GLUT2 - facilitated glucose transporter 2, B0 - Na+-dependent neutral amino acid transporter, CAT1 - cationic amino acid transporter 1, EAAC1- excitatory amino acid carrier 1, PepT1 - peptide transporter 1 
(EF140874.1), B0 (XM_001929323.4), CAT1 (AY371320.1), EAAC1 (JF521497.1) and PepT1 (AY180903.1) was carried out on an Opticon DNA Engine (Bio-Rad, Hercules, CA, USA) using SYBR Green PCR reagents (Takara, Tokyo, Japan). $\beta$-actin was chosen as the reference gene transcript (Lai et al., 2005) and the relative expression ratio of the target gene in comparison with the reference gene was calculated (Pfaffl, 2001). A standard curve was created from serial dilutions of one of the cDNA samples. A standard curve was drawn by plotting the natural log of the threshold cycle (CT) against the natural log of the number of molecules. The standard curve of each gene was run in duplicate and triplicate to obtain reliable amplification efficiency. The target gene mRNA concentration was normalized to the mRNA concentration of the reference gene, $\beta$-actin.

\section{Chemical analysis}

Chemical analysis of fiber sources, feeds and freeze-dried faeces was carried out as follows. Dry matter was determined by drying at $105^{\circ} \mathrm{C}$ for $16 \mathrm{~h}$ and all results are averages of duplicate determinations. Crude fiber, crude protein (Kjeldahl $\mathrm{N} \times 6.25$ ), calcium and phosphorus were measured by standard methods (AOAC, 1995), and energy by complete combustion in an adiabatic bomb calorimeter. Neutral detergent fiber (NDF) and acid detergent fiber (ADF) were obtained by the method of Van Soest (Van Soest et al., 1991). The contents of hemicellulose (NDF - ADF) and cellulose (ADF - (Ash + lignin)) were calculated. Additionally, in order to avoid protein contamination, sodium sulfite was added into the NDF detergent solution. Chromic oxide was determined spectrophotometrically after acid hydrolysis of the diets and faeces (van Leeuwen et al., 1996). All apparent digestibilities were calculated relative to the chromic oxide content.

\section{Statistical analysis}

A duplicate was considered as the experimental unit for all analysis. All data were subjected to one-way analysis of variance (ANOVA) for a randomized complete block design using the GLM procedure of SAS 9.0 (SAS Inst. Inc., Cary, NC). Statistical differences among treatments were separated by Tukey's multiple-range test. The alpha level used for significance was 0.05 . All data are presented as means and standard error of the mean (SEM).

\section{Results}

As shown in Table 3, there was a higher ADF and cellulose content in wheat bran than in maize fiber and soyabean fiber. Wheat bran showed a higher
Table 3. Content of crude protein and fiber components in the fiber sources, $\%$ of DM

\begin{tabular}{lcccc}
\hline Item & $\begin{array}{l}\text { Wheat } \\
\text { bran }\end{array}$ & $\begin{array}{l}\text { Maize } \\
\text { fiber }\end{array}$ & $\begin{array}{l}\text { Soyabean } \\
\text { fiber }\end{array}$ & $\begin{array}{l}\text { Pea } \\
\text { fiber }\end{array}$ \\
\hline Crude protein & 12.1 & 9.0 & 12.1 & 9.3 \\
Crude fiber & 14.5 & 13.2 & 11.0 & 24.8 \\
Neutral detergent fiber & 68.1 & 60.9 & 40.7 & 48.2 \\
Acid detergent fiber & 20.7 & 16.4 & 15.3 & 30.1 \\
Cellulose & 15.5 & 12.2 & 10.2 & 22.9 \\
Hemicellulose & 47.4 & 44.5 & 25.4 & 18.1 \\
Lignin & 1.55 & 0.38 & 0.02 & 0.08 \\
\hline
\end{tabular}

NDF and hemicellulose content than legume sources (soyabean fiber and pea fiber). With regard to animal performance, there were no significant changes $(P>0.05)$ in average daily gain (ADF) (303 to $336 \mathrm{~g}$ per day), average daily feed intake (ADFI) (479 to 518 g per day) and feed:gain (1.47 to 1.62) (data not shown).

Villus height was lower $(P<0.05)$ in pigs fed diet MF compared with diet WB (Table 4). A reduced ratio of villus height to crypt depth was observed in pigs fed diet MF compared with pigs fed diet WB $(P<0.05)$. Lower activities of sucrase $(P<0.05)$ occurred in the mid-jejunal mucosa of pigs fed diets MF and SF as compared with pigs fed diet WB, whereas lactase and maltase activities did not differ among diets (Table 3). In mid-jejunal digesta, pigs fed diets $S F$ and $P F$ had lower activities of trypsin $(P<0.05)$ compared with pigs fed diet WB. Pigs fed diets MF and PF showed lower activities of amylase $(P<0.05)$ than pigs fed diet WB. Higher lipase activities $(P<0.05)$ occurred in pigs fed diet WB than in pigs fed diets SF and PF.

Table 4. Effect of dietary fiber source fed for $30 \mathrm{~d}$ on mid-jejunal morphology and digestive enzyme activities of weaned piglets

\begin{tabular}{|c|c|c|c|c|c|c|}
\hline \multirow{2}{*}{ Item } & \multicolumn{4}{|c|}{ Experimental diets ${ }^{1}$} & \multirow{2}{*}{ SEM } & \multirow{2}{*}{$P$} \\
\hline & WB & MF & SF & PF & & \\
\hline \multicolumn{7}{|l|}{ Morphology } \\
\hline villus height, $\mu \mathrm{m}$ & $414^{\mathrm{a}}$ & $298^{b}$ & $363^{\mathrm{ab}}$ & $364^{\mathrm{ab}}$ & 25.1 & 0.046 \\
\hline crypt depth, $\mu m$ & 283 & 275 & 248 & 316 & 33.5 & 0.619 \\
\hline $\begin{array}{l}\text { villus height/ } \\
\text { crypt depth }\end{array}$ & $1.49^{\mathrm{a}}$ & $1.03^{b}$ & $1.47^{\mathrm{a}}$ & a $1.23^{\text {ab }}$ & 0.08 & 0.014 \\
\hline \multicolumn{7}{|c|}{ Enzyme activities, $\mathrm{U} \cdot \mathrm{mg}^{-1}$ protein } \\
\hline lactase $^{2}$ & 18.6 & 21.4 & 12.5 & 22.8 & 3.55 & 0.258 \\
\hline maltase $^{2}$ & 79.3 & 74.1 & 86.2 & 69.9 & 4.04 & 0.115 \\
\hline sucrase $^{2}$ & $81.0^{\mathrm{a}}$ & $39.9^{b}$ & $41.5^{b}$ & $79.1^{\mathrm{a}}$ & 8.10 & 0.006 \\
\hline trypsin ${ }^{3}$ & $192^{\mathrm{a}}$ & $110^{\mathrm{ab}}$ & $82^{b}$ & $63^{b}$ & 17.3 & 0.006 \\
\hline amylase $^{3}$ & $108^{\mathrm{a}}$ & $49^{b}$ & $106^{\mathrm{a}}$ & $38^{b}$ & 9.8 & $<0.001$ \\
\hline lipase $^{3}$ & $1670^{\mathrm{a}}$ & $1353^{\mathrm{a}}$ & $909^{b}$ & $532^{c}$ & 88.5 & $<0.001$ \\
\hline
\end{tabular}

${ }^{1}$ see Table $1 ;{ }^{2}$ mucosa samples; ${ }^{3}$ digesta samples; SEM - standard error of the mean, $n=5$ (1 piglet per pen); ${ }^{a b}$ means with different superscipts within a row are significantly different at $P<0.05$ 


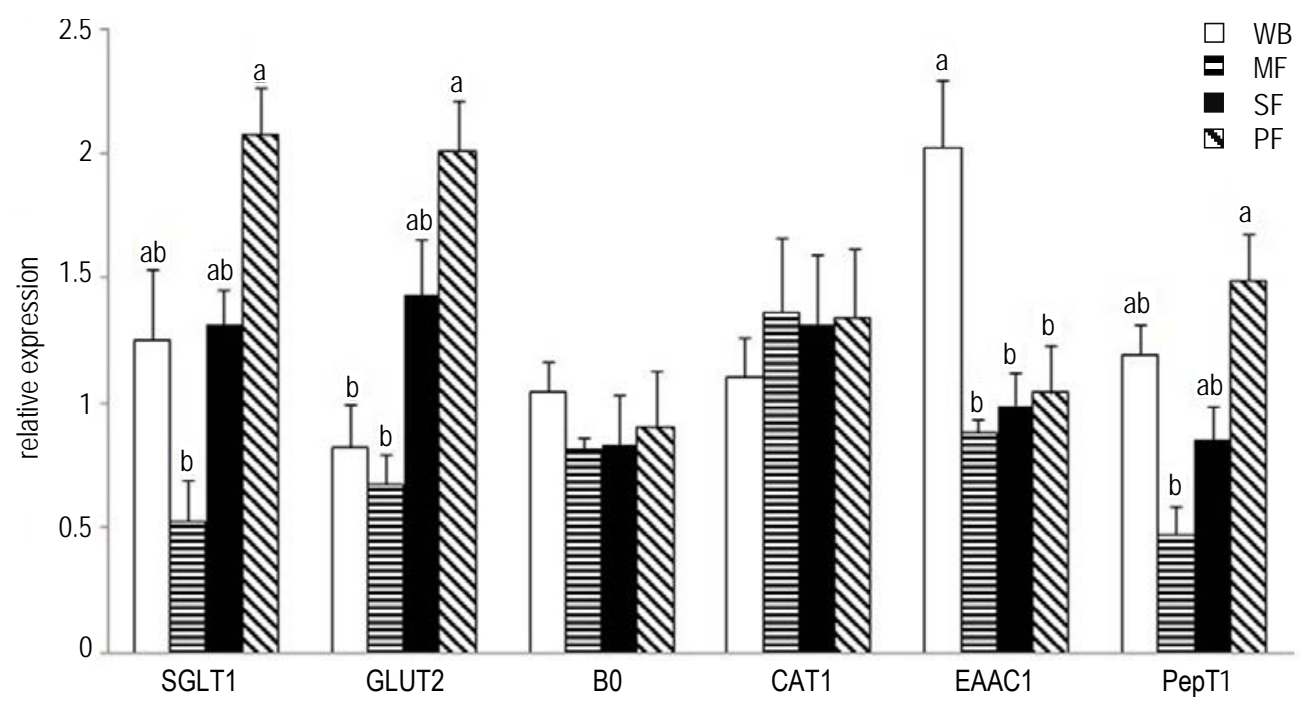

Figure 1. Effect of dietary fiber source fed for $30 \mathrm{~d}$ on gene expression of nutrient transporters in mid-jejunal mucosa in weaned piglets. Values are means, $n=5$ ( 1 piglet per pen). Treatments without common superscript differ significantly from each other, $P<0.05$. Experimental diets: WB - wheat bran, MF - maize fiber, SF - soyabean fiber, PF - pea fiber, SGLT1 - Na+-glucose co-transporter 1, GLUT2 - facilitated glucose transporter 2, B0 - Nat-dependent neutral amino acid transporter, CAT1 - cationic amino acid transporter 1, EAAC1 - excitatory amino acid carrier 1, PepT1 - peptide transporter 1

As shown in Figure 1, higher GLUT2 mRNA levels $(P<0.05)$ were also observed in pigs fed diet PF compared with pigs fed diet WB. Pigs fed diet WB showed a substantially higher expression of EAAC1 $(P<0.05)$ compared with the other treatments. Supplementation with PF increased SGLT1, GLUT2 and PepT1 mRNA levels in mid-jejunal mucosa $(P<0.05)$ when compared with MF inclusion in the diet. There were no significant differences in $\mathrm{B} 0$ and CAT1 mRNA levels among diets.

As shown in Table 5, apparent fecal digestibility of gross energy, dry matter, organic matter, neutral detergent fiber and acid detergent fiber was different among all diets and decreased in the order $\mathrm{SF}>\mathrm{PF}>\mathrm{MF}>\mathrm{WB}(P<0.05)$. For $\mathrm{CP}$, piglets fed diets $\mathrm{SF}$ and $\mathrm{PF}$ had higher digestibility coefficients

Table 5. Effect of dietary fiber source on apparent faecal digestibility in weaned piglets, \%

\begin{tabular}{lllllll}
\hline \multirow{2}{*}{ Item } & \multicolumn{6}{l}{ Experimental diets } \\
\cline { 2 - 5 } & WB & MF & SF & PF & \multirow{2}{*}{ SEM } & \multirow{2}{*}{$P$} \\
\hline GE & $84.8^{\mathrm{d}}$ & $87.3^{\mathrm{c}}$ & $94.0^{\mathrm{a}}$ & $90.0^{\mathrm{b}}$ & 0.78 & $<0.001$ \\
DM & $84.4^{\mathrm{d}}$ & $87.2^{\mathrm{c}}$ & $93.7^{\mathrm{a}}$ & $89.9^{\mathrm{b}}$ & 0.79 & $<0.001$ \\
OM & $85.9^{\mathrm{d}}$ & $88.8^{\mathrm{c}}$ & $94.8^{\mathrm{a}}$ & $91.0^{\mathrm{b}}$ & 0.75 & 0.001 \\
CP & $82.5^{\mathrm{c}}$ & $82.1^{\mathrm{c}}$ & $90.0^{\mathrm{a}}$ & $85.3^{\mathrm{b}}$ & 0.75 & 0.001 \\
NDF & $54.6^{\mathrm{d}}$ & $67.4^{\mathrm{c}}$ & $85.2^{\mathrm{a}}$ & $74.5^{\mathrm{b}}$ & 2.62 & 0.001 \\
ADF & $48.0^{\mathrm{d}}$ & $66.5^{\mathrm{c}}$ & $88.8^{\mathrm{a}}$ & $80.8^{\mathrm{b}}$ & 3.62 & 0.001 \\
Ca & $59.3^{\mathrm{ab}}$ & $54.4^{\mathrm{b}}$ & $55.9^{\mathrm{b}}$ & $65.5^{\mathrm{a}}$ & 1.44 & 0.016 \\
P & $37.3^{\mathrm{c}}$ & $44.9^{\mathrm{b}}$ & $65.8^{\mathrm{a}}$ & $48.4^{\mathrm{b}}$ & 2.47 & 0.001 \\
\hline
\end{tabular}

GE - gross energy, DM - dry matter, OM - organic matter, CP - crude protein, NDF - neutral detergent fiber, ADF - acid detergent fiber, $\mathrm{Ca}$ - calcium, $\mathrm{P}$ - phosphorus; ${ }^{1}$ see Table 1 ; ${ }^{\mathrm{a}-\mathrm{d}}$ means with different superscipts within a row are significantly different at $P<0.05$; SEM - standard error of the mean, $n=5$ ( 5 piglets per pen) than pigs fed diets WB. Feeding diets MF, SF and PF resulted in higher phosphorus apparent fecal digestibility compared with feeding diet WB.

\section{Discussion}

The current experiment showed that feeding weaned piglets for $30 \mathrm{~d}$ with different fiber sources had varied effects on several parameters of midjejunal digestive function. First, among the disaccharidase activities, sucrase showed large differences between diet WB and the other dietary fiber sources. Also Khokhar (1994) found that the activities of small intestinal disaccharidases were significantly changed in rats fed different fiber sources. The lower sucrase activities in mid-jejunal mucosa in pigs fed MF as compared with WB might be linked to lower villus height. It is known that villous atrophy is associated with reduced mucosal enzyme activities (Hedemann et al., 2006) or, conversely, longer villi correspond to higher disaccharidase activities due to increased maturity of the enterocytes (Pluske et al., 1996). In contrast, sucrase activity in the SF-fed piglets was also lower, but it did not correspond to significantly shorter villi as compared with WB.

Besides differences in brush-border enzyme activities, pancreatic enzyme activities in digesta were also affected by fiber source. Previous studies indicated that pure lignin and cellulose are the most powerful inhibitors of pancreatic enzyme activity (amylase, trypsin and lipase) in vitro (Hansen, 1986). However, WB showed the highest jejunal pancreatic 
enzyme activities, but represents the highest lignin content and the second highest cellulose content. It is likely that the differences in cellulose and lignin contents among the fibers are too small to explain these observations. They are more likely attributable to the different physicochemical properties (e.g., viscosity and fermentability) of dietary fiber (Wenk, 2001).

The small intestines of dogs fed fermentable fiber (beet pulp and oligofructose) had 95\% higher capacity for carrier-mediated glucose uptake than those of dogs fed a diet with nonfermentable fiber (cellulose) (Buddington et al., 1999), which suggests that fermentable fiber is beneficial for improving intestinal nutrient absorption by regulating nutrient carriers. We previously showed that PF is fermented more (higher total volatile fatty acids (VFA) concentration) in the upper colon than MF (Chen et al., 2013). Tappenden et al. (2003) proposed that VFA, as the main end-products of fermentation in the digestive tract, play an important role in modulating the gene expression of brushborder sodium/glucose co-transporter. This is supported by the results of the present study showing that PF could affect absorption capacity of glucose and small peptides by up-regulating the mRNA levels of glucose transporters (SGLT1, GLUT2) and small peptide transporter (PepT1), respectively, as compared with MF. Moreover, the positive effects of WB on nutrient transporters appear to be related to the ADF and cellulose contents in our study, as reflected by the higher contents of these components in WB and PF, whereas the higher GLUT2 and lower EAAC1 gene expression levels in piglets fed diet $\mathrm{PF}$ indicate that $\mathrm{PF}$ favors glucose transport and hinders acidic amino acid transport compared with WB.

Further, our results show higher apparent fecal digestibility of major nutrients in pigs fed legume fibers (SF and PF) than in pigs fed diet WB. This is in accordance with Laplace et al. (1989), who reported higher fecal digestibility of energy in pigs fed soyabean hulls in their diet than in pigs fed diet WB. Moreover, we found that the apparent fecal digestibility of GE, DM and OM was promoted as fiber (NDF and ADF) digestibility increased, which indicates that the higher digestibility of energy, DM and $\mathrm{OM}$ may be a consequence of a higher level of digestible NDF and ADF (Longland et al., 1994; Freire et al., 2000). Previous studies reported that a high level of fermentation of fiber was found not only in the growing pig (Chabeauti et al., 1994), but also in post-weaning piglets (Freire et al., 2000). According to Van Soest et al. (1991), NDF comprises the insoluble fiber fraction in the feed. Thus, the content of insoluble fiber was higher in diet WB than in the legume fibers (SF and PF) used in our study. In the present study, higher digestibility (i.e., of GE, DM, $\mathrm{OM}$ and $\mathrm{CP}$ ) was found in pigs fed diets $\mathrm{SF}$ and $\mathrm{PF}$ compared with pigs fed diet WB, suggesting that the digestibility of these nutrients was reduced as the insoluble fiber (i.e., NDF) content increased (Schedle et al., 2008). However, the lowest apparent fecal digestibility of GE, DM, OM and CP occurred in pigs fed WB, in contrast to higher jejunal villi length and higher digestive enzyme activities in comparison with the other diets. This may be related to a lower digesta transit time in the total intestinal tract (Freire et al., 2000; Wilfart et al., 2007a) resulting in lower apparent fecal digestibility in pigs fed diet WB than in pigs fed the other diets.

\section{Conclusions}

The present data indicate that there are differences in jejunal digestive physiology characteristics and nutrient apparent fecal digestibility between piglets fed diets differing in fiber source. Although pigs fed diet containing wheat bran had a superior jejunal morphology and the highest digestive enzyme activities, they also had the lowest apparent fecal digestibility, especially compared with diets with soyabean fiber and pea fiber, which indicates that the apparent fecal digestibility in piglets fed different sources of fiber does not always correlate with jejunal digestive physiology characteristics.

\section{Acknowledgments}

This study was supported by the earmarked fund for China Agriculture Research System (CARS-36). The corresponding author holds patents related to the research. The authors declare that they have no conflict of interest.

\section{References}

AOAC, 1995. Association of Official Analytical Chemists, Official Methods of Analysis. $16^{\text {th }}$ Edition. Arlington, VA

Buddington R.K., Buddington K.K., Sunvold G.D., 1999. Influence of fermentable fiber on small intestinal dimensions and transport of glucose and proline in dogs. Amer. J. Ve.t Res. 60, 354-358

Chabeauti E., Noblet J., Carre Â B., 1994. Digestion of plant cell walls from four different sources in growing pigs. Anim. Feed Sci. Tech. 31, 207-213

Chen H., Mao X., He J., Yu B., Huang Z., Yu J., Zheng P., Chen D., 2013. Dietary fiber affects intestinal mucosal barrier function and regulates intestinal bacteria in weaning piglets. Brit. J. Nutr. 110, 1837-1848 
Freire J.P.B., Guerreiro A.J.G., Cunha L.F., Aumaitre A., 2000. Effect of dietary fibre source on total tract digestibility, caecum volatile fatty acids and digestive transit time in the weaned piglet. Anim. Feed Sci. Tech. 87, 71-83

Hansen W.E., 1986. Effect of dietary fiber on proteolytic pancreaticenzymes in vitro. Int. J. Pancreatol. 1, 341-351

Hedemann M.S., Eskildsen M., Laerke H.N., Pedersen C., Lindberg J.E., Laurinen P., Knudsen K.E.B., 2006. Intestinal morphology and enzymatic activity in newly weaned pigs fed contrasting fiber concentrations and fiber properties. J. Anim. Sci. 84, 1375-1386

Hooda S., Metzler-Zebeli B.U., Vasanthan T., Zijlstra R.T., 2010. Effects of viscosity and fermentability of purified non-starch polysaccharides on ileal and total tract nutrient digestibility in ileal-cannulated grower pigs. Livest. Sci. 134, 79-81

Hu Y., Smith D.E., Ma K., Jappar D., Thomas W., Hillgren K.M., 2008. Targeted disruption of peptide transporter Pept1 gene in mice significantly reduces dipeptide absorption in intestine. Mol. Pharm. 5, 1122-1130

Khokhar S., 1994. Dietary-fibers - their effects on intestinal digestive enzyme-activities. J. Nutr. Biochem. 5, 176-180

Lai C.H., Yin J.D., Li D.F., Zhao L.D., Qiao S.Y., Xing J.J., 2005. Conjugated linoleic acid attenuates the production and gene expression of proinflammatory cytokines in weaned pigs challenged with lipopolysaccharide. J Nutr. 135, 239-244

Laplace J.P., Darcyvrillon B., Perez J.M., Henry Y., Giger S., Sauvant D., 1989. Associative effects between 2 fiber sources on ileal and overall digestibilities of amino-acids, energy and cell-wall components in growing-pigs. Brit. J. Nutr. 61, 75-87

Longland A.C., Carruthers J., Low A.G., 1994. The ability of piglets 4 to 8 weeks old to digest and perform on diets containing 2 contrasting sources of nonstarch polysaccharide. Anim. Prod. $58,405-410$

Ma Y.X., Li D.F., Qiao S.Y., Huang C.H., Han I.K., 2002. The effects of fiber source on organ weight, digesta $\mathrm{pH}$, specific activities of digestive enzymes and bacterial activity in the gastrointestinal tract of piglets. Asian Australas. J. Anim. 15, 1482-1488
Pfaffl M.W., 2001. A new mathematical model for relative quantification in real-time RT-PCR. Nucleic Acids Res. 29, e45

Pluske J.R., Williams I.H., Aherne F.X., 1996. Maintenance of villous height and crypt depth in piglets by providing continuous nutrition after weaning. Anim. Sci. 62, 131-144

Regnault T.R.H., de Vrijer B., Battaglia F.C., 2002. Transport and metabolism of amino acids in placenta. Endocrine 19, 23-41

Roder P.V., Geillinger K.E., Zietek T.S., Thorens B., Koepsell H., Daniel H., 2014. The role of SGLT1 and GLUT2 in intestinal glucose transport and sensing. Plos One. 9, e89977

Schedle K., Plitzner C., Ettle T., Zhao L., Domig K.J., Windisch W., 2008. Effects of insoluble dietary fibre differing in lignin on performance, gut microbiology, and digestibility in weanling piglets. Arch. Anim. Nutr. 62, 141-151

Tappenden K.A., Albin D.M., Bartholome A.L., Mangian H.F., 2003. Glucagon-like peptide-2 and short-chain fatty acids: A new twist to an old story. J. Nutr. 133, 3717-3720

van Leeuwen P., Veldman A., Boisen S., Deuring K., Van Kempen G.J., Derksen G.B., Verstegen M.W., Schaafsma G., 1996. Apparent ileal dry matter and crude protein digestibility of rations fed to pigs and determined with the use of chromic oxide $\left(\mathrm{Cr}_{2} \mathrm{O}_{3}\right)$ and acid-insoluble ash as digestive markers. Brit. J. Nutr. 76 , 551-562

Van Soest P.J., Robertson J.B., Lewis B.A., 1991. Methods for dietary fiber, neutral detergent fiber, and nonstarch polysaccharides in relation to animal nutrition. J. Dairy Sci. 74, 3583-3597

Wenk C., 2001. The role of dietary fibre in the digestive physiology of the pig. Anim. Feed Sci Tech. 90, 21-33

Wenk C., Zurcher U., 1990. Energy utilization by swine of nutritive fiber-rich by-products from the milling and food industry. Arch. Tierernähr. 40, 423-430

Wilfart A., Montagne L., Simmins H., Noblet J., van Milgen J., 2007a. Digesta transit in different segments of the gastrointestinal tract of pigs as affected by insoluble fibre supplied by wheat bran. Brit. J. Nutr. 98, 54-62

Wilfart A., Montagne L., Simmins P.H., van Milgen J., Noblet J., $2007 \mathrm{~b}$. Sites of nutrient digestion in growing pigs: Effect of dietary fiber. J. Anim. Sci. 85, 976-983 